\title{
PROFESSOR SETON HOWARD FREDERICK LLOYD, C.B.E., M.A., F.B.A., A.R.I.B.A. $1902-1996$
}

Seton Lloyd, who died in hospital in Oxford on 7 January 1996 at the age of 93, was one of the last surviving pioneer archaeologists who put Near Eastern archaeology on to a sound, professional footing and established the special procedures necessary for excavating Near Eastern mounds. He was born on 30 May 1902 at Edgbaston, Birmingham, the second of eight children, into a family connected with Lloyds Bank (his grandfather had been a Director) and Lloyds Insurance. His father was a "shadowy" figure who became stone deaf during his honeymoon so that relationships with his children were difficult. Seton's mother was from a military family and he adored her. She was a great influence and he was able to base parts of his memoirs (The Interval, 1986) on his numerous letters to her.

He studied at the Architectural Association in London, qualifying in 1926, and spent two years as Sir Edwyn Lutyens' assistant before setting up a small private architectural practice with two friends in 1928. That same year one of his partners got engaged to be married and was not, therefore, in a position to take up the post of architect on the Tell el-Amarna excavations in Egypt. Seton went to Egypt instead. Thus began the "professional transformation" which was to produce one of this century's great field archaeologists.

The director at Amarna, Henri Frankfort, engaged Seton Lloyd for his next venture on behalf of the Oriental Institute of the University of Chicago, namely the excavations in the Diyala Region north-east of Baghdad. Seton designed and supervised the building of the excavation house at Tell Asmar, and worked on the sites of Tell Asmar, Khafajeh, Tell Agrab and Ishchali until 1937. During these excavations the technique of tracing mud-brick walls, first developed by the Germans, was perfected and Lloyd carried out some early experiments in the uses of kite photography in archaeology. He contributed to many of the resulting publications, which produced the framework for the previously little-known Early Dynastic Period in Mesopotamia. The peculiar problems associated with the excavation of tells were later addressed by Lloyd in a series of lectures given in Edinburgh and published as Mounds of the Near East (1963). He also worked briefly with Loud at Khorsabad and, together with Thorkild Jacobsen, discovered the huge stone aqueduct built by Sennacherib about 700 вC to bring water to his capital at Nineveh (Sennacherib's Aqueduct at Jerwan, with Jacobsen, 1935). In all these undertakings his training as an architect was invaluable for planning the buildings and recording the antiquities. He also wrote the first of many books aimed at the general reader: Mesopotamia - Excavations on Sumerian sites (1936). During this time he was briefly married; much later his ex-wife Joanne was to marry Jacobsen.

In 1937 and 1939 Seton joined John Garstang, who was excavating a prehistoric mound outside Mersin on the south coast of Turkey. In between he carried out a survey in the Sinjar district of northern Iraq (published in the journal Iraq in 1938) which identified a large number of sites, many of which have since been excavated, among them Tell el-Rimah and Yarim Tepe, and at one of which, Grai Resh, he conducted a small rescue excavation. His appointment in 1939 to the post of Adviser to the Directorate General of Antiquities in Iraq led to his spending much of the war in Baghdad and Jerusalem. He was responsible for moving a pair of huge winged, human-headed bulls from Khorsabad to the site of the Museum in Baghdad, for setting up the Iraq Museum (since moved to new premises), and for undertaking a series of excavations with Iraqi colleagues at sites carefully selected to fill crucial gaps in the archaeological record of ancient Mesopotamia: 'Uqair, Hassuna, Tell Harmal, Aqar Quf and Eridu. A generation of young Iraqis was initiated in the techniques of excavation which had been developed in the Diyala. It was very much to his credit that Seton was able to effect with such success the transition from the high-profile, big-budget excavations of the Oriental Institute to the shoe-string improvisation of archaeology on a small scale under war-time stringencies. He gave talks, organised visits of sites and wrote booklets and articles for the soldiers stationed in Iraq so as to stimulate their interest in the country in which they found themselves. He also wrote two of his most successful books: Twin Rivers (1943) and Foundations in the Dust (1947) which have frequently been re-issued and translated. His beautiful 
South Gate house (now a shop and craft centre) became a meeting place for Iraqis and foreigners alike. Visitors included, in 1943, Ulrica Fitzwilliams Hyde, known as Hydie, who was accompanied by two tame chameleons named Sodom and Gomorrah. He and Hydie were married in Cairo in 1944.

In 1948 Seton accepted the post of first Director of the newly established British Institute of Archaeology at Ankara. Little was then known of the archaeological sequence on the Anatolian plateau so, in order to remedy the situation, Seton undertook an excavation at the mound of Polatl, west of Ankara. Subsequently, with David Storm-Rice, he worked at Sultantepe and Harran, where cuneiform archives and stelae were excavated, and carried out a survey of the Seljuk fortress and harbour at Alanya. He also spent several seasons excavating a Chalcolithic and Bronze Age city at Beycesultan in western Turkey, subsequently published by him and James Mellaart. This was clearly an important city, perhaps the capital of the state of Arzawa mentioned in Hittite records, but unfortunately no written documents of any sort were recovered. He and Hydie travelled extensively throughout Turkey and welcomed many to the Institute, including the present writer for whom the experience led to a career in archaeology.

Seton Lloyd retired as Director in 1961 and returned to England. His book The Art of the Ancient Near East was published that same year and subsequently translated into German, Dutch, Spanish, Italian and Russian. He and Hydie spent much time and love on Woolstone Lodge, their beautiful house just below the Uffington White Horse, and made it yet another welcoming place for family, friends, colleagues and students.

Indeed, from 1962 to 1969 the latter formed an important ingredient in Seton's life when he succeeded Max Mallowan as Professor of Western Asiatic Archaeology at the Institute of Archaeology, part of the University of London. Here many of us benefited from his first-hand knowledge of sites, pottery and artefacts, his ability to make a ground plan come alive, and his wellordered lectures. In 1965, with Charles Burney as co-director, Seton Lloyd led the first team of foreign archaeologists to work in Urartu, after eastern Turkey ceased to be a military zone. During a very successful first season at the site of Kayalidere, which overlooked a ford across the Euphrates, all the ingredients of a typical Urartian citadel were discovered: a temple, huge storage jars with hieroglyphic inscriptions, hoards of metalwork and rock-cut tombs. That the permit was not renewed, however, was a great disappointment, although it may have saved our lives as we were not there at the time of the devastating Varto earthquake.

Seton also continued to write for the general reader as well as completing all the reports on his excavations, contributing articles to learned journals and writing book reviews. The Archaeology of Mesopotamia (1978), which was translated and re-issued, became a text-book and is still on course reading lists. To the bibliography published in the Festschrift volume of the journal Iraq in 1982 and updated in The Interval in 1986 (p. 179), several volumes can be added, including Eridu (1981 with F. Safar and M. A. Mustafa). He loved Woolstone where he could indulge in two of his favourite pastimes, fishing and shooting. Hydie, his constant companion, who worked beside him on his excavations and illustrated many of his publications, died in 1987 . He continued to live at Woolstone, which he rarely left, and, in 1989, published Ancient Turkey which has since appeared in paperback. More recently his short-term memory began to fail but he still enjoyed reminiscing about the past while smoking a pipe. He never let standards slip and always dressed with style and was careful of his personal appearance. He still walked up to the trout pool and round the garden every day if possible. A stroke on New Year's Eve necessitated hospitalisation and he died a week later.

He leaves three children, seven grandchildren and two great-grandchildren, has passed on his knowledge to several generations of archaeologists who are now working in museums and universities all over the world and, through his writings, has made Near Eastern Archaeology come alive for a world-wide audience.

Seton Lloyd's career did not go unrecognised. He was awarded the Hashemite Order of Rafidhain when he left Baghdad, appointed OBE in 1949, and CBE in 1957. He became a Fellow of the British Academy in 1955 and was a Fellow of the Society of Antiquaries. He received the Lawrence of Arabia Memorial Medal in 1971 and the Gertrude Bell Memorial Medal in 1979. In 1960 he was awarded an Honorary MA from Edinburgh University, was made Emeritus Professor upon his 


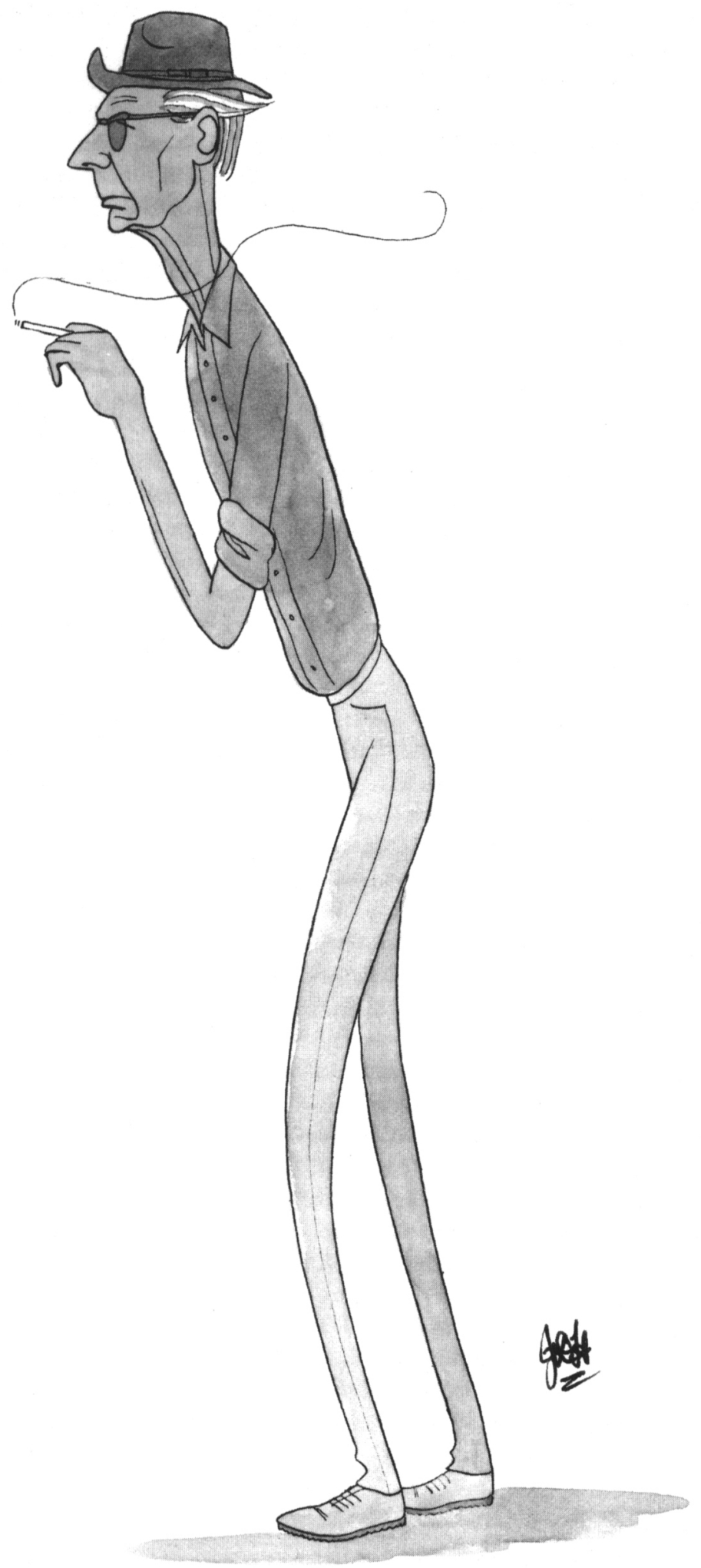

Seton Lloyd at Kayalıdere in 1965 (reproduced courtesy of J. D. Hawkins) 
retirement in 1969, and had Festschrifts dedicated to him in 1972 (Anatolian Studies) and 1982 (Iraq - including a Bibliography). He served on the Councils of the British School of Archaeology in Iraq and the British Institute of Archaeology at Ankara, most recently as Vice-President, and he was a Corresponding Member of the German Archaeological Institute.

In the many tributes which have appeared since his death, several have alluded to his ability to identify problems and pick the appropriate sites to supply the answers. One "admired particularly his combination of archaeological and architectural ability and his readiness to produce a synthesis of both disciplines". A Turkish colleague said simply that he was a "büyük adam". He was, indeed, a great man. 